\title{
KNOWLEDGE SHARING IN VIRTUAL TEAMS: A RESEARCH IN INFORMATION TECHNOLOGY COMPANIES IN VIETNAM
}

\author{
HUYNH THI MINH CHAU \\ Ho Chi Minh City University of Technology, Vietnam National University, \\ HCMC - htmchau@hcmut.edu.vn \\ NGUYEN MANH TUAN \\ Ho Chi Minh City University of Technology, Vietnam National University, \\ HCMC - nmtuan@hcmut.edu.vn \\ HANG LE CAM PHUONG \\ Ho Chi Minh City University of Technology, Vietnam National University, \\ HCMC - hlcphuong@hcmut.edu.vn
}

(Received: February 21, 2017; Revised: April 6, 2017; Accepted: April 10, 2017)

\begin{abstract}
Nowadays, virtual teams bring both benefits and drawbacks to companies, especially to information technology companies. Improving virtual team performance is a requisite to speed up the development of information technology companies. This article conducts a quantitative research on virtual team members in Vietnam's information technology companies to investigate the relationships between social capital, risk of opportunistic behaviors, knowledge sharing, and team performance in the situation of virtual teams. The study uses SPSS and AMOS to analyze data collected from 268 valid samples. We find out a reliable 15 -variable scale which can be used to measure structural social capital, cognitive social capital, rational social capital, risk of opportunistic behaviors, knowledge sharing and virtual team performance. The results show positive effects of structural social capital and cognitive social capital on knowledge sharing and virtual team performance. The findings also reveal negative effects of risk of opportunistic behaviors on knowledge sharing and virtual team performance and a positive correlation between knowledge sharing and virtual team performance. This article can be used as reference for managers to build solutions for improving virtual team performance in information technology companies in Vietnam.
\end{abstract}

Keywords: knowledge sharing; social capital; risk of opportunistic behaviors; team performance; virtual team.

\section{Introduction}

Successful organizations are increasingly using information technology (IT) as a primary trigger to adapt more quickly to everchanging competitive landscapes and customer requirements (Davidow \& Malone, 1992; Jarvenpaa \& Ives, 1994). In the context of the increasing de-centralization and globalization of work processes, many organizations have responded to the dynamic environments by introducing virtual teams.

Virtual team (VT) is "a group of people who interact through interdependent task guided by common purpose" and "works across space, time, and organizational boundaries with link strengthened by webs of communication technologies" (Lipnack \& Stamps, 1997). According to Henry \& Hartzler (1998), VT is "a group of people who works closely together even though they are geographically separated by miles or even continents" and as "intact workgroups or cross functional groups brought together to tackle a project for a finite period of time through a combination of technologies" A growing number of organizations are implementing VTs or plan to implement VTs in the near future (Lipnack \& Stamps, 1997; McDonough et al., 2001) and the use of VTs is expected to continue to grow (Carmel \& Agarwal, 2001; 
McDonough et al., 2001).

VTs are usually formed for various reasons. Basically, they help improve the organization's ability to source the best talent and to benefit the organization's clients by providing geographically specific services or knowledge (DeRosa \& Lepsinger, 2010). VTs also allow organizations to respond faster to increased competition, and provide greater flexibility to individuals working from home or on the road (B. S. Bell \& Kozlowski, 2002). Furthermore, improvements in collaborative technology allow VTs to work together in ways that seem impossible to them in the past. Organizations sometimes form VTs through more opportunistic drivers, responding to a particular event or need (DeRosa \& Lepsinger, 2010).

While offering a wide range of potential benefits to organizations (Townsend et al., 1998), the implementation of VTs will be risky if organizations fail to adequately address the many challenges present in the virtual context (Iacono \& Weisband, 1997; Victor \& Stephens, 1994). In Vietnam, many companies have been using VTs as a new form of teamwork. As VTs are still something new, managers should be aware of how to apply this form to their business. IT companies are among those which use VTs most regularly. So, it is necessary to conduct a research on VTs especially in IT companies in Vietnam.

Knowledge sharing is considered a fundamental activity through which employees can contribute to knowledge application, innovation, and ultimately the competitive advantage of the organization (Jackson et al., 2006). Knowledge sharing between team members allows organizations to exploit knowledge-based resources (Cabrera \& Cabrera, 2005; Damodaran \& Olphert, 2000; Davenport \& Prusak, 1998). Much research has shown that knowledge sharing is positively correlated to reduction of production costs, faster completion of new product development projects, team performance, firm innovation capabilities, and firm performance including sales growth and revenue from new products and services (e.g.,Arthur \& Huntley, 2005; Collins \& Smith, 2006; Cummings, 2004; Hansen, 2002; Lin, 2007; Mesmer-Magnus \& DeChurch, 2009). Knowledge sharing is vital for effective collaboration in VTs. Hence, organizations need to make efforts to ensure a sufficient share of knowledge among teams. A successful agile VT needs shared knowledge on the tasks and how to get information such as team members, its goal and development process. Though knowledge sharing helps enhance communication and collaboration, VTs face many challenges in terms of values and norms, lack of face-to-face communication, time-zone differences, and difficulties in building and maintaining trust (Moe et al., 2016). The unique characteristics of VTs make it more difficult to share knowledge among the geographically separated members. It is necessary to address this issue by looking at how the process of knowledge transfer takes place in a VT (Hong \& Vai, 2008). Hence, conducting a research on knowledge sharing in VTs can be useful both in literature and in reality.

Social capital is an important motivation of knowledge sharing in teams. Social capital typically emphasizes on resources for accomplishing goals and how to allocate these resources in networks of individuals, groups, organizations, or communities (Burt, 2000; Inkpen \& Tsang, 2005; Nahapiet \& Ghoshal, 1998). Resources arising from social capital are both actual and potential resources that can be exploited in the future (Bourdieu, 1986). Social capital in teams include resources such as information accessibility, mutual trust, and emotional support located in social relationships among team members (Oh et al., 2004). Until now, most research on team social capital has focused on examining the relationship between social capital and team performance (Gupta et al., 2011; Oh et al., 2004; Pil \& Leana, 2009; Reagans et al., 
2004; Reagans \& Zuckerman, 2001; van Emmerik \& Brenninkmeijer, 2009). Many studies show a positive relationship between team social capital and team performance, and more recently, between team social capital and virtual team performance. For examples, Robert Jr et al. (2008) found that structural and cognitive capital were more important to knowledge integration when communicating by lean digital network than communicating directly by team members; relational capital directly impacted knowledge integration equally, regardless of the communication media used by the team. Knowledge integration, in turn, affected team decision quality, suggesting that social capital influences team performance in part by increasing a team's ability to integrate knowledge. According to Fuller \& Summers (2017), a major impact from turnover and the ensuing inconsistency in VT membership is the loss of human and social capital which with ensuing effects on relational development, individual interactions, and behaviors that support the healthy exchange of ideas. Hence, in this article, we examined social capital with it three dimension (structural, relational, and cognitive) as an antecedent of knowledge sharing, and also virtual team performance.

Inter-organizational relationships are inherently temporal, unstable, and disfavored (Williamson, 1991). The stability of interorganizational relationships is affected by factors such as opportunism, complexity in monitoring behaviors, and difficulty in coordination among partners (Park \& Ungson, 2001). These characteristics are relevant to knowledge exchange between VT members and affect the success of the cooperative relationship. Depending on the participants' private incentives, interorganizational relationships may generate either cooperative or competitive behaviors between partners (Gulati, 1995). Cooperative inter-organizational relationships may fail due to opportunistic hazards that arise as each firm pursues its own individual interests rather than collective interests. Opportunistic behaviors may allow immediate gratification of short-term goals of a partner without the need of facing the uncertainty of long-term returns. The vulnerability due to a partner's self-interested behaviors is exacerbated when relevant resources and behaviors are not readily transparent (Park \& Ungson, 2001). Concerns about this kind of risk may inhibit VT members from sharing knowledge. Hence, in this article, we suppose that risk of opportunistic behaviors does not facilitate knowledge sharing behavior in VTs and thus negatively affects virtual team performance.

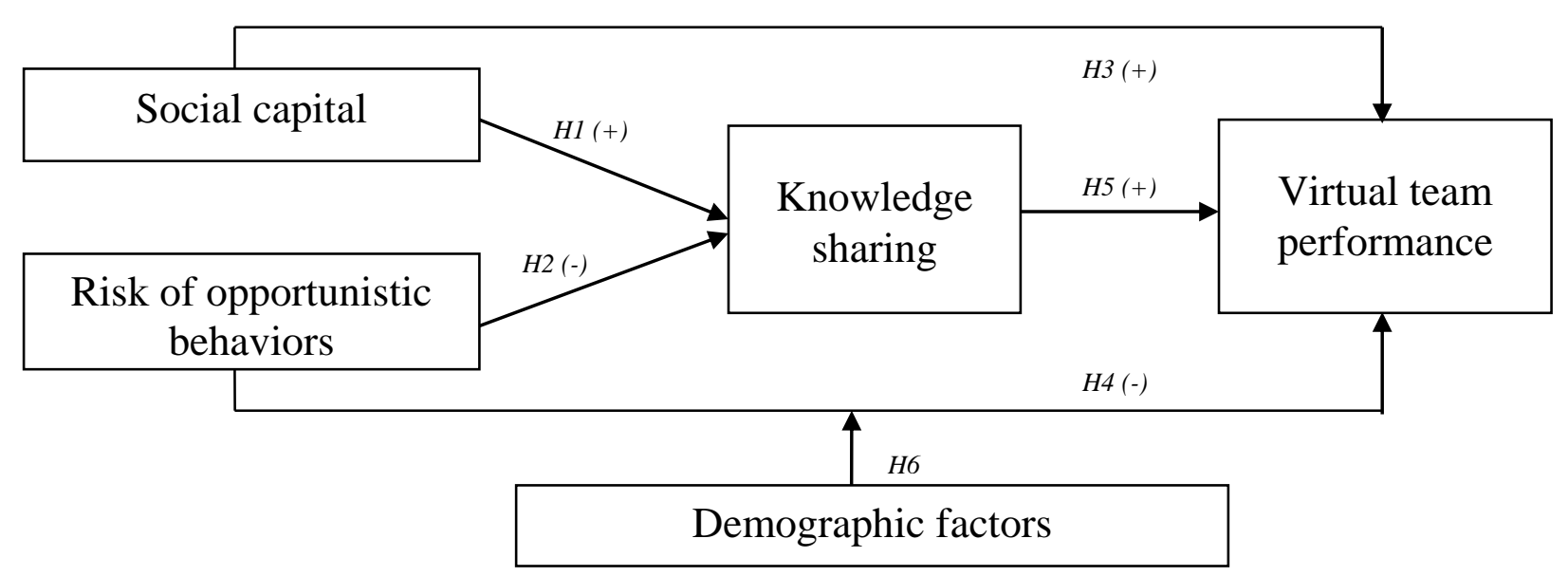

Figure 1. Conceptual framework 


\section{Definitions and scales}

\subsection{Social capital}

Social capital (SC) has been discussed by many scholars since the seminal works of Bourdieu (1986) and Coleman (1988). It highlights the concerns about cohesion in social dynamics as an important social resource. According to Bourdieu (1986) and Coleman (1988), SC is a reciprocal expectation of economic benefits among individuals and groups through cooperation. Accordingly, many studies have examined the role of SC from different perspectives since economic performance, to human capital development, as well regions and countries development (Nahapiet \& Ghoshal, 1998). All of them generating commonalities and at the same time a variety of definitions, because of the broad scope that the subject encompasses: complex network connections between social and economic perspectives (Robison et al., 2002). Recently, many studies have proven the effect of SC on virtual team performance (Chua et al., 2012; Clopton, 2011; Hyejung Lee et al., 2013; Lind \& Culler, 2011; Maurer et al., 2011; Powell \& Eddleston, 2013; Sparrowe et al., 2001; Stam et al., 2014; Vila et al., 2013; Yu \& Junshu, 2013).

Nahapiet \& Ghoshal (1998) define three dimensions of SC - structural, cognitive and relational. The structural SC (SSC) is defined as the social interactions, including the patterns and strength of ties, among the members of a collective (Pearson et al., 2008). It includes the number and intensity of available relationships, how members address each other, and the proportions of strong, weak or conflicting relationships. The cognitive SC (CSC) is several resources providing shared representations, interpretations, and systems of meaning among parties (Nahapiet \& Ghoshal, 1998). Moreover, it comprises the group's shared vision and purpose, its unique language, and deeply embedded narratives and culture (Pearson et al., 2008). In other words, the cognitive dimension refers to the way members perceive their reality. Lastly, the relational SC (RSC) comprises the resources created through personal relationships including trust, norms, obligations, and identity (Nahapiet \& Ghoshal, 1998).

In this article, SSC is measured using four items adapted from Chow \& Chan (2008) and Nahapiet \& Ghoshal (1998) including: "In general, I have a very good relationship with my partners" (SSC_1), "My partners know what knowledge I have at my disposal" (SSC_2), "I know what knowledge could be relevant to which partner" (SSC_3), "In my $V T, I$ know who has knowledge that is relevant to me at their disposal" (SSC_4). CSC is measured using three items adopted from Chow \& Chan (2008) including: "My partner and I always agree on what is important at work" (CSC_1), "My partners and I always share the same ambitions and vision at work" (CSC_2), "My partners and I are always enthusiastic about pursing the collective goals and missions of the whole organization" (CSC_3). RSC is measured using a four-item scale derived from Chow \& Chan (2008) and Nahapiet \& Ghoshal (1998) including: "I feel connected to my partners" (RSC_1), "I know my partners will always try and help me out if I get into difficulties" (RSC_2), "I can trust my partners to lend me a hand if I need it" (RSC_3), "I can rely on my partners when I need support in my work" (RSC_4) The SC items are rated on a fivepoint Likert scale ranging from 1 ("strongly disagree") to 5 ("strongly agree").

\subsection{Knowledge sharing}

Knowledge sharing (KS) is a process of communication between two or more participants involving the acquisition and provision of knowledge (Heeseok Lee \& Choi, 2003; Lin, 2007). KS processes can be classified into knowledge collecting (KC) and knowledge donating (KD) (Van den Hooff \& de Leeuw van Weenen, 2004; Van Den Hooff 
\& De Ridder, 2004). KC entails "consulting colleagues in order to get them to share their intellectual capital" (Van Den Hooff \& De Ridder, 2004, p.118) whereas KD entails "communicating to others what one's personal intellectual capital is" (Van den Hooff \& De Ridder, 2004, p.118).

In this article, a three-item scale developed by Van den Hooff \& Van Weenen (2004) is used to measure KC including: "I share information I have with partners when they ask for it" (KC_1), "I share my skills with partners when they ask for it" (KC_2), "Partners in my VT share their skills with me when I ask them to" (KC_3). KD is measured using a three-item scale adapted from an investigation by Van den Hooff \& Van Weenen (ibid), including: "When I have learned something new, I tell my partners about it" (KD_1), "When they have learned something new, my partners tell me about it" (KD_2), "KS among partners is considered normal in my VT" (KD_3). The items are rated on a five-point Likert scale ranging from 1 ("strongly disagree") to 5 ("strongly agree").

\subsection{Risk of opportunistic behaviors}

Opportunism (opportunistic behaviors) means self-interest seeking with guile, involving some kind of deliberate deceit and the absence of moral restraint (Williamson, 1985). It could include deliberately withholding or distorting information, performance shirking, or failing to fulfill promises and obligations. It occurs in business transactions especially where performance measures are ambiguous, and where goals of trading partners are incongruent (Ouchi, 1980). Risk of opportunistic behaviors (ROB) is an inherent threat in any interorganizational relationship - e.g. VTs. To the extent a dyadic relationship entails $\mathrm{KS}$ between VT members, the very exchange process is vulnerable to this risk. This is the case motivated by self-interest in any dyadic exchange scenario - the self-interest case.

In this article, ROB is measured using four-items adapted Parkhe (1993), including: "Complete honesty does not pay when dealing with my partners" (ROB_1), "Sometimes my partners alters the facts of VT process in order to get what they need" (ROB_2), "My partners has sometimes promised to do things without actually doing them later" (ROB_3), "My partners seem to feel that it is OK to do anything in their means that will help further their interests" (ROB_4). The items are rated on a five-point Likert scale ranging from 1 ("strongly disagree") to 5 ("strongly agree").

\subsection{Virtual team performance}

The extent to which a team's output meets or exceeds its key stakeholders' standards is a core indicator of team performance (Hackman \& Walton, 1986). In this article, we rely on assessments from each VT member's response to evaluate virtual team performance (VTP). These responses are based on their perception of their VTP. Using a five-point agreement scale ranging from 1 ("strongly disagree") to 5 ("strongly agree"), each VT member scored his/her VT on four-items: "I was 100\% satisfied with the outcome of this VT" (VTP_1), "Based on my satisfaction with this year's audit, I am very likely to recommend this VT to other partners" (VTP_2), "This VT communicated effectively (i.e., in a timely, clear, concise, non-confrontational way) with me" (VTP_31), "This VT was excellent in communicating the value of it to $m e^{\prime \prime}$ (VTP_4).

\subsection{Demographic factors}

Team members' characteristics affecting team performance are of interest to researchers and practitioners (e.g.,S. T. Bell, 2007; Carpenter et al., 2004). A particular interest is how diversity on team member demographic variables (e.g., race, age, educational background) is related to team performance (e.g., Ancona \& Caldwell, 1992; Kochan et al., 2003; Mannix \& Neale, 2005; Milliken \& Martins, 1996; Pelled et al., 1999). The increased attention paid to demographic diversity is primarily due to the 
changing nature of the workforce and to social policy concerns surrounding diversity issues (Jackson et al., 1995).

To study the effects of demographic diversity on VTs, 07 demographic factors (DFs) are examined including: (1) characteristics of individual such as Sex (DF_S), Position in VT (DF_P), Age (DF_A); (2) characteristics of VT such as Team size (DF_TS), Team lifespan (DF_TL); (3) characteristics of company such as Company's size (DF_CS).

\section{Hypotheses}

10 hypotheses about 03 groups of relationships are made including:

- Hypotheses about the relationships between SC, ROB and KS: [H1a] SSC has a positive effect on KS; [H1b] CSC has a positive effect on KS; [H1c] RSC has a positive effect on KS; [H2] ROB has a negative effect on KS.

- Hypotheses about the relationships between SC, ROB and VTP: [H3a] SSC has a positive effect on VTP; [H3b] CSC has a positive effect on VTP; [H3c] RSC has a positive effect on VTP; [H5] ROB has a negative effect on VTP.

- Hypotheses about the relationships between KS and VTP: [H4] KS has a positive effect on VTP.

- Hypotheses about the moderating effect of demographic factors: [H6] There are differences in CSC, SSC, RSC, ROB, KS and VTP depending on DFs.

\section{Research methodology}

Research objects are individuals. A quantitative research is conducted by sending questionnaires via Google docs to VT members who are working in VTs at IT companies in Vietnam. Non probability convenience sampling, using 02 sort-out questions in the beginning of questionnaire, including: [Q1] Being a member of (at least) a VT in an IT company in Vietnam; [Q2] Spending (at least) $50 \%$ of working time on doing tasks in that VT. Only the answers who say "Yes" to both these 02 questions are chosen as research objects.

In the middle section of questionnaire, the ratings of agreement on 25 variables are collected (including 04 variables for SSC, 04 variables for RSC, 03 variables for CSC, 03 variables for $\mathrm{KC}, 03$ variables for $\mathrm{KD}, 04$ variables for ROB, and 04 variables for VTP).

The last section of questionnaire contains 06 questions about DFs. There are 268 valid samples (excluded 26 invalid samples) meeting the requirement of minimum sample size. After being coded and cleaned, data are analyzed by SPSS and AMOS with these statistical tools: descriptive statistics, exploratory factor analysis (EFA), confirmatory factor analysis (CFA), structural equation modeling analysis (SEM), and analysis of variance (ANOVA).

\section{Research results}

\subsection{Descriptive statistics}

5.1.1. Characteristics of individual

(1) Sex (DF_S): 155 male $(57.84 \%)$ and 113 female $(42.16 \%)$.

(2) Position in VT (DF_P): $20.15 \%$ managers of at least $01 \mathrm{VT}$; $79.85 \%$ not a manager of any VT.

(3) Age $\left(D F_{-} A\right): 35.07 \%$ from 26 to 35 ; $22.39 \%$ from 36 to $45 ; 20.52 \%$ from 46 to 55 ; $16.79 \%$ under 26; and $5.22 \%$ above 55 .

\subsubsection{Characteristics of VT}

(1) Team size (DF_TS): 52 VTs have 7 members $(19.40 \%)$; 50 VTs have 6 members (18.66\%), 47 VTs have 5 members (17.54\%); 37 VTs have 4 members (13.81\%); 26 VTs have 10 members $(9.7 \%) ; 21$ VTs have 3 members $(7.84 \%) ; 16$ VTs have 8 members (5.97\%); 11 VTs have 9 members $(4.1 \%)$; and 8 VTs have more than 10 members (2.99\%).

(2) Team life-cycle (DF_TL): 85 VTs exist from 3 months to under 6 months (31.72\%); 72 VTs exist more than 1 year (26.87\%); 61 VTs exist from 6 months to under 1 year (22.76\%); 33 VTs exist from 1 month to under 3 months (12.31\%); 17 VTs exist under 1 month (6.34\%). 
5.1.3. Characteristics of company

Company's size (DF_CS): 215 respondents are working in small sized companies $(80.22 \%), 53$ respondents are working in medium sized companies (19.78\%), no respondents works in large sized companies.

5.2. Research model and hypothesis testing 5.2.1. Exploratory factor analysis (EFA) $\mathrm{KMO}$ coefficient is $0.841>0.5$, Barlett's accreditation is 6367.827 with sig $=0.000$ $<0.05$ thus EFA is appropriate to research data. EFA result is 6 components extracted from 22 variables, just as research models have been proposed. EFA factor loadings of 22 variables are from 0.641 to 0.951 (> 0.5). The total average variance extracted (AVE) is $72.49 \%$ explaining more than $70 \%$ of the variation of the data set (Table 1).

\section{Table 1}

The results of exploratory factor analysis (EFA) and Cronbach's Alpha analysis

\begin{tabular}{|c|c|c|c|c|}
\hline Latent variables & Observable variables & EFA & Cronbach's alpha & Eigenvalues \\
\hline \multirow[t]{4}{*}{ Structural social capital } & SSC_1 & 0.719 & \multirow[t]{4}{*}{0.823} & \multirow[t]{4}{*}{4.176} \\
\hline & SSC_2 & 0.739 & & \\
\hline & SSC_3 & 0.748 & & \\
\hline & SSC_4 & 0.780 & & \\
\hline \multirow[t]{3}{*}{ Cognitive social capital } & CSC_1 & 0.829 & \multirow[t]{3}{*}{0.823} & \multirow[t]{3}{*}{1.263} \\
\hline & CSC_2 & 0.775 & & \\
\hline & CSC_3 & 0.780 & & \\
\hline \multirow[t]{4}{*}{ Rational social capital } & RSC_1 & 0.681 & \multirow[t]{4}{*}{0.815} & \multirow[t]{4}{*}{2.930} \\
\hline & $\mathrm{RSC} \_2$ & 0.829 & & \\
\hline & $\mathrm{RSC} \_3$ & 0.811 & & \\
\hline & RSC_4 & 0.754 & & \\
\hline \multirow[t]{6}{*}{ Knowledge sharing } & KC_1 & 0.779 & \multirow[t]{6}{*}{0.868} & \multirow[t]{6}{*}{8.685} \\
\hline & KC_2 & 0.876 & & \\
\hline & KC_3 & 0.915 & & \\
\hline & KD_1 & 0.861 & & \\
\hline & KD_2 & 0.903 & & \\
\hline & KD_3 & 0.917 & & \\
\hline \multirow{4}{*}{$\begin{array}{l}\text { Risk of opportunistic } \\
\text { behaviors }\end{array}$} & ROB_1 & 0.850 & \multirow[t]{4}{*}{0.814} & \multirow[t]{4}{*}{1.558} \\
\hline & ROB_2 & 0.803 & & \\
\hline & ROB_3 & 0.702 & & \\
\hline & ROB_4 & 0.643 & & \\
\hline \multirow[t]{4}{*}{ Virtual team performance } & VTP_1 & 0.942 & \multirow[t]{4}{*}{0.903} & \multirow[t]{4}{*}{2.553} \\
\hline & VTP_2 & 0.875 & & \\
\hline & VTP_3 & 0.925 & & \\
\hline & VTP_4 & 0.729 & & \\
\hline
\end{tabular}


5.2.2. Reliability analysis by Cronbach's Alpha

Cronbach's Alpha coefficients of all components are from 0.709 to 0.935 (> 0.70). In each scale, corrected item-total correlation $>0.40$, each Cronbach's Alpha if item deleted is not greater than Cronbach's Alpha of scale. Thus, all components meet requirements (Hair et al., 2014).

\subsubsection{Confirmatory factor analysis (CFA)}

CFA is carried out to test how well the measured variables represent the number of constructs. First CFA result shows that the prob. of a type-I error of ROB_4's is $0.48<$ 0.5 thus ROB_4 is eliminated. Continuing to use CFA, relying on $\mathrm{MI}$ to eliminate $\mathrm{KC} \_2$, KC_3, VTP_2, VTP_3, RSC_3, KS_2, RSC_4, SSC_3, and ROB_2. The improved scale are compatible with the data with Chisquare $(\mathrm{x} 2) / \mathrm{dF}=3.605 ;$ GFI $=0.904 ; \mathrm{TLI}=$ 0.894; CFI = 0.928; RMSEA = 0,090 (Byrne, 2010). CFA loadings of all variables are from 0.621 to 0.951 .

Average variance extracted (AVE) of all components are from 0.510 to $0.742(>0,5)$ thus the scale establishes convergence validity (Fornell \& Larcker, 1981). Because AVE of all components are greater than $\mathrm{r} 2$, all components establish discriminant validity (Hair et al., 2014) (Table 2).

\section{Table 2}

The scale of social capital, risk of opportunistic behaviors, knowledge sharing and virtual team performance

\begin{tabular}{|c|c|c|c|c|c|}
\hline $\begin{array}{l}\text { Latent } \\
\text { variables }\end{array}$ & \multicolumn{2}{|c|}{ Observable variables } & CFA & CR & AVE \\
\hline \multirow{3}{*}{$\begin{array}{l}\text { Structural } \\
\text { social capital }\end{array}$} & SSC_1 & $\begin{array}{l}\text { In general, I have a very good } \\
\text { relationship with my partners }\end{array}$ & 0.621 & \multirow{3}{*}{0.757} & \multirow{3}{*}{0.742} \\
\hline & SSC_4 & $\begin{array}{l}\text { In my VT, I know who has knowledge } \\
\text { that is relevant to me at their disposal }\end{array}$ & 0.706 & & \\
\hline & SSC_2 & $\begin{array}{l}\text { My partners know what knowledge I } \\
\text { have at my disposal }\end{array}$ & 0.823 & & \\
\hline \multirow{3}{*}{$\begin{array}{l}\text { Cognitive } \\
\text { social capital }\end{array}$} & CSC_3 & $\begin{array}{l}\text { My partners and I are always } \\
\text { enthusiastic about pursing the } \\
\text { collective goals and missions of the } \\
\text { whole organization }\end{array}$ & 0.711 & \multirow{3}{*}{0.779} & \multirow{3}{*}{0.564} \\
\hline & CSC_2 & $\begin{array}{l}\text { My partners and I always share the } \\
\text { same ambitions and vision at work }\end{array}$ & 0.777 & & \\
\hline & CSC_1 & $\begin{array}{l}\text { My partners and I always agree on } \\
\text { what is important at work }\end{array}$ & 0.852 & & \\
\hline \multirow[b]{2}{*}{$\begin{array}{l}\text { Rational } \\
\text { social capital }\end{array}$} & RSC_1 & I feel connected to my partners & 0.758 & \multirow[b]{2}{*}{0.817} & \multirow[b]{2}{*}{0.510} \\
\hline & RSC_2 & $\begin{array}{l}\text { I know my partners will always try } \\
\text { and help me out if I get into } \\
\text { difficulties }\end{array}$ & 0.723 & & \\
\hline \multirow{2}{*}{$\begin{array}{l}\text { Knowledge } \\
\text { sharing }\end{array}$} & KC_1 & $\begin{array}{l}\text { I share information I have with } \\
\text { partners when they ask for it }\end{array}$ & 0.744 & \multirow{2}{*}{0.800} & \multirow{2}{*}{0.681} \\
\hline & KD_3 & $\begin{array}{l}\text { KS among partners is considered } \\
\text { normal in my VT }\end{array}$ & 0.815 & & \\
\hline
\end{tabular}




\begin{tabular}{|c|c|c|c|c|c|}
\hline \multirow{2}{*}{$\begin{array}{l}\text { Latent } \\
\text { variables }\end{array}$} & \multicolumn{2}{|c|}{ Observable variables } & \multirow{2}{*}{\begin{tabular}{|l} 
CFA \\
0.951
\end{tabular}} & \multirow[t]{2}{*}{ CR } & \multirow[t]{2}{*}{ AVE } \\
\hline & KD_1 & $\begin{array}{l}\text { When I have learned something new, I } \\
\text { tell my partners about it }\end{array}$ & & & \\
\hline \multirow{2}{*}{$\begin{array}{l}\text { Risk of } \\
\text { opportunistic } \\
\text { behaviors }\end{array}$} & ROB_1 & $\begin{array}{l}\text { Complete honesty does not pay when } \\
\text { dealing with my partners }\end{array}$ & 0.823 & \multirow[b]{2}{*}{0.785} & \multirow[b]{2}{*}{0.527} \\
\hline & ROB_3 & $\begin{array}{l}\text { My partners has sometimes promised } \\
\text { to do things without actually doing } \\
\text { them later }\end{array}$ & 0.811 & & \\
\hline \multirow{2}{*}{$\begin{array}{l}\text { Virtual team } \\
\text { performance }\end{array}$} & VTP_4 & $\begin{array}{l}\text { This VT was excellent in } \\
\text { communicating the value of it to me }\end{array}$ & 0.945 & \multirow{2}{*}{0.810} & \multirow{2}{*}{0.650} \\
\hline & VTP_1 & $\begin{array}{l}\text { I was } 100 \% \text { satisfied with the } \\
\text { outcome of this VT }\end{array}$ & 0.906 & & \\
\hline
\end{tabular}

\section{(SEM)}

5.2.4. Structural equation modeling analysis

SEM result with ML estimation shows that the model conforms to Chi-square $(\mathrm{x} 2) / \mathrm{dF}=1.474 \quad(<3)$ with $\mathrm{p}=0.000$, $\mathrm{AGFI}=0.839(>0.8) ;$ TLI $=0.928, \mathrm{CFI}=$ $0.936(>0.9)$; RMSEA $=0.043(<0.08)$. CSC has a positive effect on KS with $\gamma=0.241(\mathrm{p}$ $=0.001)$, CSC has a positive effect on VTP with $\gamma=0,380(\mathrm{p}=0.000)$, thus [H1a] and [H3a] are supported. SSC positively affects KS with $\gamma=0.261(p=0.000)$ and SSC positively affects VTP with $\gamma=0.232$ (p=
$0.000)$, thus $[\mathrm{H} 1 \mathrm{~b}]$ and $[\mathrm{H} 3 \mathrm{~b}]$ are supported. KS positively affects VTP with $\gamma=0.267(\mathrm{p}=$ $0.001)$, thus [H5] is supported. ROB negatively affects KS with $\gamma=-0.231(\mathrm{p}=$ $0.008)$, ROB negatively affects VTP with $\gamma=$ $-0.345(\mathrm{p}=0.000)$, thus $[\mathrm{H} 1 \mathrm{c}]$ and $[\mathrm{H} 3 \mathrm{c}]$ are supported. Although RSC has a negative effect on KS with $\gamma=-0.199(p=0.102)$ and RSC has a negative effect on VTP with $\gamma=$ 0.120 ( $\mathrm{p}=0.209$ ), but $\mathrm{p}>0.05$, so these effects are not statistically significant, [H1c] and $[\mathrm{H} 3 \mathrm{c}]$ are not supported (Hair et al., 2014) (Table 3).

\section{Table 3}

The relationships between components of scale

\begin{tabular}{|c|c|c|c|c|c|c|}
\hline Hypothesis & Relationship & Estimate $-\gamma$ & SE & CR & p-value & Result \\
\hline H1a & KS <- SSC & 0.241 & 0.072 & 3.232 & 0.001 & Supported \\
\hline H1b & KS <- CSC & 0.261 & 0.096 & 3.495 & $* * *$ & Supported \\
\hline H1c & KS <- RSC & -0.199 & 0.107 & -1.753 & 0.102 & Not supported \\
\hline H2 & KS <- ROB & -0.231 & 0.057 & -2.637 & 0.008 & Supported \\
\hline H3a & VTP <- SSC & 0.380 & 0.096 & 5.568 & $* * *$ & Supported \\
\hline H3b & VTP <- CSC & 0.232 & 0.116 & 3.797 & $* * *$ & Supported \\
\hline H3c & VTP <- RSC & -0.120 & 0.127 & -1.260 & 0.209 & Not supported \\
\hline H4 & VTP <- ROB & -0.345 & 0.070 & -4.622 & $* * *$ & Supported \\
\hline H5 & VTP <- KS & 0.267 & 0.074 & 5.411 & $* * *$ & Supported \\
\hline
\end{tabular}




\subsubsection{Analysis of variance (ANOVA)}

ANOVA test is used to analyze the differences of SSC, CSC, RSC, ROB, KS, and VTP depending on DFs. The result shows differences among CSC depending on Sex (DF_S); differences among KS depending on Position in VT (DF_P); differences among
RSC and among KS depending on Age (DF_A). There's no difference among components depending on Team size (DF_TS), Team lifespan (DF_TL) and Company's size (DF_CS). Differences of few components depending on DFs, [H6] are not supported (Table 4).

\section{Table 4}

The differences of components depending on DFs

\begin{tabular}{|l|l|l|l|l|l|l|}
\hline DFs & SSC & CSC & RSC & ROB & KS & VTP \\
\hline DF_S & - & X** & - & - & - & - \\
\hline DF_P & - & - & - & - & $\mathrm{x}^{* *}$ & - \\
\hline DF_A & - & - & $\mathrm{x} * * *$ & - & $\mathrm{x}$ & - \\
\hline DF_TS & - & - & - & - & - & - \\
\hline DF_TL & - & - & - & - & - & - \\
\hline DF_CS & - & - & - & - & - & - \\
\hline
\end{tabular}

In sum, 7 out of 10 hypotheses are supported, including [H1a], [H1b], [H2], [H3a], [H3b], [H4], and [H5].



Figure 2. Theoretical model after tested $(* \mathrm{p}<0.05 ; * * \mathrm{p}<0.01 ; * * * \mathrm{p}<0.001)$

\section{Theoretical contributions and limitations}

This article investigates the effects of social capital, risk of opportunistic behaviors and knowledge sharing on virtual team performance based on the fact that virtualteamwork is increasingly popular while there was too few research on this topic. Based on the theories of social capital, risk of opportunistic behaviors, knowledge sharing and virtual team performance, we conduct a quantitative research using SPSS and AMOS to analyze the data collected by questionnaire.

The result employs a reliable 15-variable scale to measure structural social capital, cognitive social capital, rational social capital, risk of opportunistic behaviors, knowledge sharing and team performance in virtual team. The result reveals positive effects of structural social capital and cognitive social capital on knowledge sharing and virtual team 
performance as well as positive effects of knowledge sharing on virtual team performance. It also shows negative effects of risk of opportunistic behaviors on knowledge sharing and virtual team performance as well as negative effects of rational social capital on knowledge sharing and virtual team performance. However, these results are not statistically significant.

Although we use sort-out questions, data is obtained conveniently so it should not be equal and random. Besides, quantitative research should be conducted at team level instead of at individual level to enhance the validity of the result. However, future studies should approach these concepts from multidimensions to investigate insight into the effects of social capital, risk of opportunistic behaviors and knowledge sharing on virtual team performance. The result can be improved by adding more observable variables into the model, expanding sample size, changing sample selection method, performing qualitative research before quantitative research to better adjust the scale of IT companies in Vietnam.

\section{Practical implications and conclusions}

It is essential for organizations to be more flexible and adaptable in their operations due to stricter competitive environment. This leads to an increase in organizations using virtual environments, especially using virtual teams in their work. Many researches have examined the nature of virtual teams with special interests in improving virtual team interactions and subsequent performance. However, few researches were conducted to better understand social- psychological contributors affecting virtual teams, especially in Vietnam. This article, therefore, can serve as a useful reference for managers to build solutions to improve virtual team performance in information technology companies in Vietnam.

This research gives both team leaders and members the practical and valuable insight into issues affecting virtual teams. First, the findings show a positive relationship between knowledge sharing and virtual team performance. We suggests that knowledge sharing behavior is an important mediator for transforming social capital of members to virtual team performance. Two resources of social capital (resources for providing shared representations, interpretations, meaning systems among members and resources from personal relationships such as trust, norms, obligations, and identity) considerably affect the communication process between members sharing the knowledge. Second, the findings suggest that managers pay special attention to the risks of opportunistic behaviors within virtual team because of their negative effect on both knowledge sharing and virtual team performances. The risks include deliberately withholding or distorting information, performance shirking, or failing to fulfill promises and obligation.

In conclusion, this article shows that virtual teams can be helped improve their performance by developing a dynamic knowledge sharing capability, structural and cognitive social capital. Besides, it also proves that reducing opportunistic behaviors is necessary to enhance both knowledge sharing capability and virtual team performance. Hopefully, the results can be referred to as valuable tool for both researchers and managers interested in virtual team performance

This research is funded by Hochiminh City University of Technology - VNU-HCM under grant number T-QLCN-2016-125.

\section{References}

Ancona, D. G., \& Caldwell, D. F. (1992). Bridging the boundary: External activity and performance in organizational teams. Administrative Science Quarterly, 37(4), 634-665. doi: 10.2307/2393475 
Arthur, J. B., \& Huntley, C. L. (2005). Ramping up the organizational learning curve: Assessing the impact of deliberate learning on organizational performance under gainsharing. Academy of Management Journal, 48(6), 1159-1170.

Bell, B. S., \& Kozlowski, S. W. J. (2002). A Typology of Virtual teams: Implications for Effective Leadership. Group \& Organization Management, 27, 22.

Bell, S. T. (2007). Deep-level composition variables as predictors of team performance: a meta-analysis. Journal of applied psychology, 92(3), 595.

Bourdieu, P. (1986). The Forms of Capital. In J. G. Richardson (Ed.), Handbook of Theory and Research for the Sociology of Education (pp. 241-258). New York: Greenwood Press.

Byrne, B. M. (2010). Structural Equation Modeling with AMOS: Basic Concepts, Applications, and Programming (2th ed.): Taylor and Francis Group, LLC.

Cabrera, E. F., \& Cabrera, A. (2005). Fostering knowledge sharing through people management practices. International Journal of Human Resource Management, 16, 720-735.

Carmel, E., \& Agarwal, R. (2001). Tactical approaches for alleviating distance in global software development. IEEE software, 18(2), 22-29.

Carpenter, M. A., Geletkanycz, M. A., \& Sanders, W. G. (2004). Upper echelons research revisited: Antecedents, elements, and consequences of top management team composition. Journal of management, 30(6), 749-778.

Chow, W. S., \& Chan, L. S. (2008). Social network, social trust and shared goals in organizational knowledge sharing. Information \& Management, 45(7), 458-465.

Chua, C. E. H., Lim, W.-K., Soh, C., \& Sia, S. K. (2012). Enacting Clan Control in Complex IT Projects: A Social Capital Perspective. MIS Quarterly, 36(2), 577-600.

Clopton, A. W. (2011). Social capital and team performance. Team Performance Management: An International Journal, 17(7/8), 369 - 381. doi: 10.1108/13527591111182634

Coleman, J. S. (1988). Social Capital in the Creation of Human Capital. American Journal of Sociology, 94(1988), 95-120.

Collins, C. J., \& Smith, K. G. (2006). Knowledge exchange and combination: The role of human resource practices in the performance of high-technology fir. Academy of Management Journal, 49(3), 544-560.

Cummings, J. N. (2004). Work Groups, Structural Diversity and Knowledge Sharing in a Global Organization. Management Science, 50(3), 352-364.

Damodaran, L., \& Olphert, W. (2000). Barriers and facilitators to the use of knowledge management systems. Behaviour \& Information Technology, 19(6), 405-413.

Davenport, T., \& Prusak, L. (1998). Working Knowledge: How Organizations Manage What They Know. Boston: Harvard Business School Press.

Davidow, W. H., \& Malone, M. S. (1992). The virtual corporation. Structuring and revitalizing the corporation for the 21st century. New York: Harper Business.

DeRosa, D., \& Lepsinger, R. (2010). Virtual team success. San Francisco, CA: Jossey-Bass. Dibbern, J., Winkler, J., \& Heinzl, A.(2008). Explaining variations in client extra costs between software projects offshored to India. MIS Quarterly, 32(2), 333-366.

Fornell, C., \& Larcker, D. F. (1981). Evaluating Structural Equation Models with unobservable Variables and Measurement error. Journal of Marketing Research 18(1), 39-50

Fuller, R., \& Summers, J. (2017). The Impact of Virtual Team Consistency on Individual Performance and Perceptual Outcomes Over Time. Paper presented at the Proceedings of the 50th Hawaii International Conference on System Sciences.

Gulati, R. (1995). Social Structure and Alliance Formation Patterns: A Longitudinal Analysis. Administrative Science Quarterly, 40(4), 619-652. doi: 10.2307/2393756 
Hackman, J. R., \& Walton, R. E. (1986). Leading groups in organizations. In P. S. Goodman (Ed.), Designing effective work groups (pp. 72-119). San Francisco: Jossey-Bass.

Hair, J. F., Black, W. C., Babin, B. J., \& Anderson, R. E. (2014). Multivariate Data Analysis: Pearson New International Edition (Pearson new Internaltional ed.).

Hansen, M. T. (2002). Knowledge network: Explaining effective knowledge sharing in multiunit companies. Organization science, 13(3), 232-248.

Henry, J. E., \& Hartzler, M. (1998). Tools for Virtual Teams: A Team Fitness Companion. Journal for Healthcare Quality, 20(5), 38.

Hong, J. F., \& Vai, S. (2008). Knowledge-sharing in cross-functional virtual teams. Journal of General Management, 34(2), 21.

Iacono, C. S., \& Weisband, S. (1997). Developing trust in virtual teams. Paper presented at the System Sciences, 1997, Proceedings of the Thirtieth Hawaii International Conference on.

Jackson, S. E., Chuang, C. H., Harden, E. E., Jiang, Y., \& Joseph, J. M. (2006). Toward developing human resource management systems for knowledge-intensive teamwork. In J. M. Joseph (Ed.), Research in personnel and human resources management (Vol. 25, pp. 27-70). Amsterdam: JAI.

Jackson, S. E., May, K. E., \& Whitney, K. (1995). Understanding the dynamics of diversity in decision-making teams. Team effectiveness and decision making in organizations, 204, 261.

Jarvenpaa, S. L., \& Ives, B. (1994). The global network organization of the future: Information management opportunities and challenges. Journal of management information systems, 10(4), 25-57.

Kochan, T., Bezrukova, K., Ely, R., Jackson, S. E., Joshi, A., Jehn, K., . . . Thomas, D. (2003). The effects of diversity on business performance: Report of the diversity research network. Human resource management, 42(1), 3-21.

Lee, H., \& Choi, B. (2003). Knowledge management enablers, processes, and organizational performance: An integrative view and empirical examination. Journal of management information systems, 20(1), 179-228.

Lee, H., Park, J., \& Lee, J. W. (2013). Role of Leadership Competencies and Team Social Capital in IT services. Journal of Computer Information Systems, 53(4), 11.

Lin, C. P. (2007). Knowledge sharing and firm innovation capability: An empirical study. International Journal of Manpower, 28(3/4), 315-332.

Lind, M. R., \& Culler, E. (2011). Information Technology Project Performance: The Impact of Critical Success Factors. International Journal of Information Technology Project Management, 2(4), 14-25. doi: $0.4018 /$ jitpm.2011100102

Lipnack, J., \& Stamps, J. (1997). Virtual teams Reaching Across Space, Time, and Organizations with Technology. New York: John Wiley \& Sons.

Mannix, E., \& Neale, M. A. (2005). What differences make a difference? The promise and reality of diverse teams in organizations. American Psychological Society, 6(2), 31-55.

Maurer, I., Bartsch, V., \& Ebers, M. (2011). The Value of Intra-organizational Social Capital: How it Fosters Knowledge Transfer, Innovation Performance, and Growth. Organization Studies, 32(2), 157-185. doi: $10.1177 / 0170840610394301$

McDonough, E. F., Kahn, K. B., \& Barczak, G. (2001). An investigation of the use of global, virtual, and colocated new product development teams. Journal of Product Innovation Management, 18(2), 110-120.

Mesmer-Magnus, J. R., \& DeChurch, L. A. (2009). Information sharing and team performance: A meta-analysis. Journal of Applied Psychology, 94, 535-546.

Milliken, F. J., \& Martins, L. L. (1996). Searching for common threads: Understanding the multiple effects of diversity in organizational groups. Academy of management review, 21(2), 402-433. 
Moe, N. B., Fægri, T. E., Cruzes, D. S., \& Faugstad, J. E. (2016). Enabling knowledge sharing in agile virtual teams. Paper presented at the Global Software Engineering (ICGSE), 2016 IEEE 11th International Conference on.

Nahapiet, J., \& Ghoshal, S. (1998). Social Capital, Intellectual Capital, and the Organizational Advantage. Academy of management review, 23(2), 242-266.

Ouchi, W. G. (1980). Markets, bureaucracies, and clans. Administrative Science Quarterly, 129-141.

Park, S. H., \& Ungson, G. R. (2001). Interfirm rivalry and managerial complexity: A conceptual framework of alliance failure. Organization science, 12(1), 37-53. doi: 10.1287/orsc.12.1.37.10118

Parkhe, A. (1993). Strategic alliance structuring: A game theoretic and transaction cost examination of interfirm cooperation. Academy of Management Journal, 36(4), 794-829.

Pearson, A. W., Carr, J. C., \& Shaw, J. C. (2008). Toward a theory of familiness: A social capital perspective. Entrepreneurship Theory and Practice, 32(6), 949-969.

Pelled, L. H., Eisenhardt, K. M., \& Xin, K. R. (1999). Exploring the black box: An analysis of work group diversity, conflict and performance. Administrative Science Quarterly, 44(1), 1-28.

Powell, G. N., \& Eddleston, K. A. (2013). Linking family-to-business enrichment and support to entrepreneurial success: Do female and male entrepreneurs experience different outcomes? . Journal of Business Venturing, 28(2), 261-280. doi: 10.1016/j.jbusvent.2012.02.007

Robert Jr, L. P., Dennis, A. R., \& Ahuja, M. K. (2008). Social capital and knowledge integration in digitally enabled teams. Information Systems Research, 19(3), 314-334.

Robison, L. L., Mertens, A. C., Boice, J. D., Breslow, N. E., Donaldson, S. S., Green, D. M., . . . Neglia, J. P. (2002). Study design and cohort characteristics of the childhood cancer survivor study: A multi-institutional collaborative project. Pediatric Blood \& Cancer, 38(4), 229-239.

Sparrowe, R. T., Liden, R. C., Wayne, S. J., \& Kraimer, M. L. (2001). Social networks and the performance of individuals and groups. Academy of Management Journal, 44(2), 316-325.

Stam, W., Arzlanian, S., \& Elfring, T. (2014). Social Capital of Entrepreneurs and Small Firm Performance: A Meta-Analysis of Contextual and Methodological Moderators. Journal of Business Venturing, 29(1), 152-173.

Van den Hooff, B., \& de Leeuw van Weenen, F. (2004). Committed to share: commitment and CMC use as antecedents of knowledge sharing. Knowledge and process management, 11(1), 13-24.

Van Den Hooff, B., \& De Ridder, J. A. (2004). Knowledge sharing in context: the influence of organizational commitment, communication climate and CMC use on knowledge sharing. Journal of knowledge management, $8(6), 117-130$.

Victor, B., \& Stephens, C. U. (1994). Business ethics: A synthesis of normative philosophy and empirical social science. Business Ethics Quarterly, 4(02), 145-155.

Vila, J. E., Fornoni, M., \& Palacios, D. (2013). Multidimensional Social Capital in New Ventures. The Service Industries Journal, 33(9-10), 820-832. doi: 10.1080/02642069.2013.719892

Williamson, O. E. (1985). The economics institutions of capitalism: Firms, markets, relational contracting. New York: Free Press.

Williamson, O. E. (1991). Comparative economic organization: The analysis of discrete structural alternatives. Administrative Science Quarterly, 36(2), 269-296.

Yu, C., \& Junshu, D. (2013). A Literature Review of the Effects of Social Capital --From the Personal Network Perspective. International Journal of Business and Social Science 4(12), 251-259. 